\title{
Grazing Management in Tropical Savannas: Utilization and Rest Strategies to Manipulate Rangeland Condition
}

\author{
Andrew J. Ash, ${ }^{1}$ Jeff P. Corfield, ${ }^{2}$ John G. McIvor, ${ }^{3}$ and Taoufik S. Ksiksi ${ }^{4}$ \\ Authors are ${ }^{1}$ Director, CSIRO Climate Adaptation Flagship, GPO Box 2583, Brisbane, QLD 4001, Australia; ${ }^{2}$ Research Project Officer, CSIRO, Private \\ Mail Bag, PO Aitkenvale, QLD 4814, Australia; ${ }^{3}$ Research Scientist, CSIRO, GPO Box 2583, Brisbane, QLD 4001, Australia; and ${ }^{4}$ Associate Professor, \\ Department of Biology, United Arab Emirates University, PO Box 15551, Al-Ain, United Arab Emirates.
}

\begin{abstract}
Grazing management is important for sustaining the productivity and health of rangelands. However, the effects of grazing management on herbage growth and species composition in the tropical savannas of northern Australia are not well known. In this eight-year study the influences of utilization rate and resting pastures from grazing on vegetation dynamics were measured at three sites in northeast Queensland, Australia. The sites had high, medium, and low soil fertility, and there were two land condition classes (States I and II) at each site. Severe drought occurred during the first four years, but above-average rainfall was received in the second half of the study. High utilization rates reduced biomass, perennial grass basal area, and ground cover. The reduction in biomass was due to both higher consumption and decreased primary production. State I condition plots at the high and medium soil fertility sites were initially dominated by decreaser perennial grasses, but these declined at all utilization levels, particularly the high rate. They were largely replaced by exotic perennial grasses. At the low fertility site there were no exotic grasses, and the decreaser grasses increased in all treatments, with the increases greatest in plots with low utilization or medium utilization plus resting. In the State II condition plots at the high and medium fertility sites, low or moderate utilization, led to an increase in both decreaser and exotic perennial grasses; with high utilization the decreaser perennial grasses declined and were replaced largely by exotic perennial grasses. This study clearly demonstrated that either conservative stocking with year-round grazing or a grazing system that includes some wet-season resting will help maintain land in a desirable state or help facilitate the transition from a less desirable ecological state to one more desirable for pastoral production and rangeland condition.
\end{abstract}

\section{Resumen}

El manejo del pastoreo es importante para mantener una productividad sostenida y la salud de los pastizales. Sin embargo, el efecto del manejo del pastoreo en el crecimiento del forraje y la composición de las especies en las sabanas tropicales del norte de Australia se desconocen. En este estudio de 8 años se consideró la influencia de la tasa de utilización y el descanso del pastoreo en potreros en la dinámica de la vegetación. El estudio se llevó a cabo en tres sitios en el noroeste de Queensland Australia. Los sitios tenían niveles de fertilidad en el suelo altos, mediano y bajo, y se tenían dos clases de condición (Estado I y II) en cada sitio. Se presentó una sequía muy severa durante los primeros 4 años pero durante la otra mitad del estudio la precipitación fue por arriba del promedio. Las altas tasas de utilización redujeron la biomasa y el área basal y cobertura aérea de las gramíneas perenes. La reducción en la biomasa se debió tanto al alto consumo y la reducción de la producción primaria. Las parcelas en el estado de condición I en los suelos con fertilidad mediana y alta estuvieron dominadas al inicio por gramíneas perenes de especies decrecientes pero estas disminuyeron en todos los niveles de utilización, particularmente en los niveles altos. Estas especies fueron sustituidas por especies de gramíneas exóticas. En los sitios con suelos de baja fertilidad no se encontraron gramíneas exóticas y las gramíneas decrecientes se incrementaron en todos los tratamientos, con el máximo incremento en las parcelas con baja y mediana utilización más descanso del pastoreo. Las parcelas en la condición de estado II en los sitios con fertilidad alta y media, la utilización baja o moderada llevo al incremento de especies decrecientes y de pastos exóticos; con una utilización alta las gramíneas perennes decrecientes disminuyeron y fueron remplazadas en su mayoría por las gramíneas perenes exóticas. Este estudio demuestra claramente que una carga animal conservadora con el pastoreo durante todo el año o un sistema de pastoreo que incluya una estación húmeda con descanso ayudara a mantener el área en un estado deseable o ayudará a facilitar la transición de un estado ecológicamente no deseable a uno más deseable para una producción pastoral y condición del pastizal.

Key Words: disturbance, drought, soil fertility, state and transition model, vegetation dynamics

\section{INTRODUCTION}

Research was partially funded by Meat and Livestock Australia.

Correspondence: Dr Andrew Ash, Director, CSIRO Climate Adaptation Flagship, GPO Box 2583,

Brisbane, QLD 4001, Australia. Email: andrew.ash@csiro.au

Manuscript received 6 August 2009; manuscript accepted 23 January 2011.
A major challenge facing pastoralists in highly variable rangeland environments is balancing animal numbers with forage supply. When animal numbers exceed carrying capacity for a sustained period there can be a loss of decreaser perennial species and associated changes in species composition (O'Con- 
nor 1994; Ash et al. 1995; Holechek et al. 2003) that underpin landscape productivity. Changes in species composition are usually accelerated when both drought and high grazing pressures occur concurrently (Hodgkinson 1995; Fynn and O'Connor 2000; Fuhlendorf et al. 2001). Drought tends to reduce plant vigor and basal area of perennial species, while grazing tends to be a major driver of changes in species composition. However, undesirable changes in species composition and declining primary productivity are not always immediately mirrored by declining secondary productivity (Ash et al. 2002). This weak coupling and/or lag between undesirable changes in land condition and changes in livestock productivity provides an additional challenge for management because there is often no immediate impetus to change grazing practices in response to changing land condition.

The rangelands of northeastern Australia, which are dominated by open eucalypt woodlands (Eucalyptus spp., Corymbia spp.) with an understory of $\mathrm{C}_{4}$ tussock grasses, are subject to particularly high interannual rainfall variability $(\mathrm{CV}>40 \%)$ (Ash and McIvor 2005) as a result of frequent El Niño Southern Oscillation events (Allan et al. 1996). Management adaptations to this large variability in rainfall and even larger variability in primary productivity (Ash and McIvor 2005) include use of drought-resistant Bos indicus cattle and widespread use of supplements to support cattle during dry years (Landsberg et al. 1998). These technological solutions enable producers to maintain high herd numbers, and during poor growing seasons in a variable environment this means grazing pressures are frequently high, and as a consequence changes in vegetation condition, soil erosion, and landscape function are of increasing concern (Gardener et al. 1990; Landsberg et al. 1998).

In response to these issues there has been increasing emphasis within the pastoral industry to develop grazing strategies that maintain land in good condition or restore land that has deteriorated. Effective vegetation management requires a sound ecological underpinning, and in northern Australia this has been achieved through the use of state and transition models (Westoby et al. 1989) as an organizing framework (Ash et al. 1994; Brown 1994). The application of state and transition models in Australia has been on the basis that both equilibrium (gradual change, reversible) and nonequilibrium (multiple states, thresholds, irreversible) dynamics can operate within the one model (Watson et al. 1996; Briske et al. 2005). Incorporating both equilibrium and nonequilibrium dynamics overcomes the potential for management to underemphasize the need for grazing management in the belief that vegetation change is event driven and episodic and therefore largely out of their control. In northern Australia, state and transition models have been largely used in communicating concepts of vegetation change, though there have been attempts to more quantitatively describe states and transitions (Scanlan 1994; Phelps and Bosch 2002). Similarly, in North America, the most effective application of state and transition models has been in evaluating benefits and risks of different management options in an ecological context (Bestelmeyer et al. 2003).

Managing vegetation condition and transitions between states in commercial enterprises needs to be better informed by process and system response to different grazing management strategies and their interaction with climate, which is a key driver of system dynamics (Fynn and O'Connor 2000;
Fuhlendorf et al. 2001). In the tropical woodlands of northeastern Australia, recommendations on grazing management can draw only on limited experimentation that has focused on year-round grazing systems based on land dominated by decreaser perennial grasses. This research has shown that stocking rates that equate to about $25-30 \%$ utilization of annual pasture growth are sustainable (McIvor and Gardener 1995; Landsberg et al. 1998). It is also known that continuous grazing with high stocking rates can have deleterious impacts on land condition either as patches within a pasture or over whole pasture areas (Mott 1987; McIvor and Orr 1991; Tothill and Gillies 1992; McIvor et al. 2005). Land in a desirable condition from both an ecological and a pastoral perspective (no accelerated erosion, little bare ground, dominated by perennial grasses, few weeds) will produce more forage than land in an undesirable condition (accelerated erosion, bare ground, few perennial grasses, many weeds). For example, in a study at a number of sites in northern Australia, total biomass production from land dominated by annual grasses and forbs was only $10-20 \%$ of that from the same land type dominated by decreaser perennial grasses (McIvor et al. 1995).

There is, however, little understanding of what grazing strategies may be required to shift land condition from an undesirable state to one dominated by palatable, perennial grasses and whether the pathways of degradation and recovery are similar or if there are hysteresis effects (Briske et al. 2003). Resting, or removal of grazing for strategic periods of recovery, has been recommended as a grazing strategy to eliminate or reduce negative impacts of grazing (e.g., Pratt and Gwyne 1977; Tainton 1999). In this paper, the definition of rest has been adopted from international terminology to mean an area of land that is intentionally left ungrazed for a specific time (weeks, growing season, or up to a year). In many subtropical and tropical grazing lands, $\mathrm{C}_{4}$ perennial grasses are most sensitive to defoliation early in the growing season (Smith 1960; Norman 1965; Tainton et al. 1977; Mott 1987; Ash and McIvor 1998), so resting during the growing season might provide an option for recovery of perennial grasses. In contrast, temperate grasslands that are dominated by cool-season $\mathrm{C}_{3}$ grasses are often most sensitive to grazing when grasses are actively growing, flowering, and setting seed, and rest at that time may be beneficial (Dowling et al. 1996). Regardless of environment the evidence is fairly clear that rotational grazing does not increase pasture or animal production (Briske et al. 2008). However, the role of grazing strategies that provide rest to vegetation at critical times to encourage recovery of decreaser perennial grasses has not been objectively assessed.

This study adopted a state and transition model approach to manipulating pasture composition in the tropical woodlands of northern Australia, a region important for cattle production but that is also important because the ecosystems are to a large degree structurally intact and of high biodiversity value (Woinarski et al. 2007). A particular focus of this study was to understand how land in contrasting condition responded to different grazing management strategies in a highly variable rainfall environment and the implications for management. Key hypotheses guiding this experiment are the following:

- Year-round grazing at low utilization rates or rest during the early part of the wet-season will facilitate the transition from a vegetation state dominated by increaser perennial grasses, 
Table 1. Major characteristics of the three study sites.

\begin{tabular}{|c|c|c|c|}
\hline & Site A & Site B & Site C \\
\hline \multicolumn{4}{|l|}{ Site } \\
\hline Location & Hillgrove and Eumara Springs stations & Cardigan station & Lakeview and Allan Hills stations \\
\hline Latitude & $19.7^{\circ} \mathrm{S}$ & $20.2^{\circ} S$ & $20.4^{\circ} \mathrm{S}$ \\
\hline Longitude & $145.8^{\circ} \mathrm{E}$ & $146.7^{\circ} \mathrm{E}$ & $145.8^{\circ} \mathrm{E}$ \\
\hline Elevation $(\mathrm{m})$ & 300 & 240 & 355 \\
\hline Annual rainfall (mm) mean (SD) & $547(244)$ & $676(273)$ & $641(264)$ \\
\hline \multicolumn{4}{|l|}{ Soil } \\
\hline Parent geology & Basalt & Granodiorite & Sedimentary \\
\hline Great Group (Soil Survey Staff 1990) & Ustochrept & Paleustalf & Paleustalf \\
\hline Australian classification (Isbell 1996) & Red Ferrosol & Red Chromosol & Yellow Kandosol \\
\hline Soil texture $(0-10 \mathrm{~cm})(\%$ clay $)$ & 46 & 17 & 12 \\
\hline Available water-holding capacity (mm) & 150 & 100 & 140 \\
\hline Total $N(0-10 \mathrm{~cm})(\%)$ & 0.11 & 0.05 & 0.03 \\
\hline Extractable $P(0-10 \mathrm{~cm})(\mathrm{ppm})$ & 50 & 6 & 3 \\
\hline \multicolumn{4}{|l|}{ Vegetation } \\
\hline \multirow[t]{2}{*}{ Dominant tree species } & Eucalyptus crebra & Eucalyptus drepanophylla & Eucalyptus melanophloia \\
\hline & Corymbia erythrophloia & Corymbia erythrophloia & \\
\hline \multirow[t]{2}{*}{ Dominant $\mathrm{C}_{4}$ tussock grasses } & Bothriochloa ewartiana & Heteropogon contortus & Bothriochloa ewartiana \\
\hline & Dichanthium sericeum & Chrysopogon fallax & Chrysopogon fallax \\
\hline Tree basal area $\left(\mathrm{m}^{2} \cdot \mathrm{ha}^{-1}\right)$ & 5.5 & 3.5 & 3.8 \\
\hline
\end{tabular}

annual grasses, and forbs to one dominated by decreaser perennial grasses.

- High utilization rates will lead to a loss of decreaser perennial grasses and replacement by increaser perennial grasses, annual grasses, or forbs.

- Rainfall variability will interact with utilization rate to influence transitions between vegetation states.

\section{MATERIALS AND METHODS}

\section{Sites}

Study sites were established on three land types of contrasting soil fertility, tree density, and herbaceous vegetation condition in the Charters Towers district of northeast Queensland. Site characteristics are presented in Table 1, drawing on earlier work conducted on two of the land types (McIvor and Gardener 1995) and information from a regional survey (Rogers et al. 1999). In brief, Site A had a well-drained and fertile soil, Site B had a soil that was well drained and was moderately fertile, and Site $\mathrm{C}$ had a poorly drained soil of low fertility with soil phosphorus levels considered deficient for animal production (Kerridge et al. 1990).

The climate in the region is semiarid tropical, with $80 \%$ of the rainfall occurring between November and April. The average length of the growing season is approximately 100 days, but this is highly variable in response to large interannual rainfall variability. All three land types are characterized by an open woodland with a eucalypt overstory and an understory dominated by tropical $\mathrm{C}_{4}$ tussock grasses when undisturbed. A wide diversity of annual grasses, forbs, and legumes are also common on each land type.

\section{Treatments}

At each of the three sites two contrasting land condition classes were selected using a simple state and transition model for the region (McIvor and Scanlan 1994). The state and transition model is shown in Figure 1. For this study, land in States I and II were selected. State I was dominated (proportion of biomass) by palatable, decreaser perennial grasses such as black speargrass (Heteropogon contortus [L.] P. Beauv. ex Roem. \& Schult.), desert bluegrass (Bothriochloa ewartiana [Domin] C. E. Hubb.), and Queensland bluegrass (Dichanthium

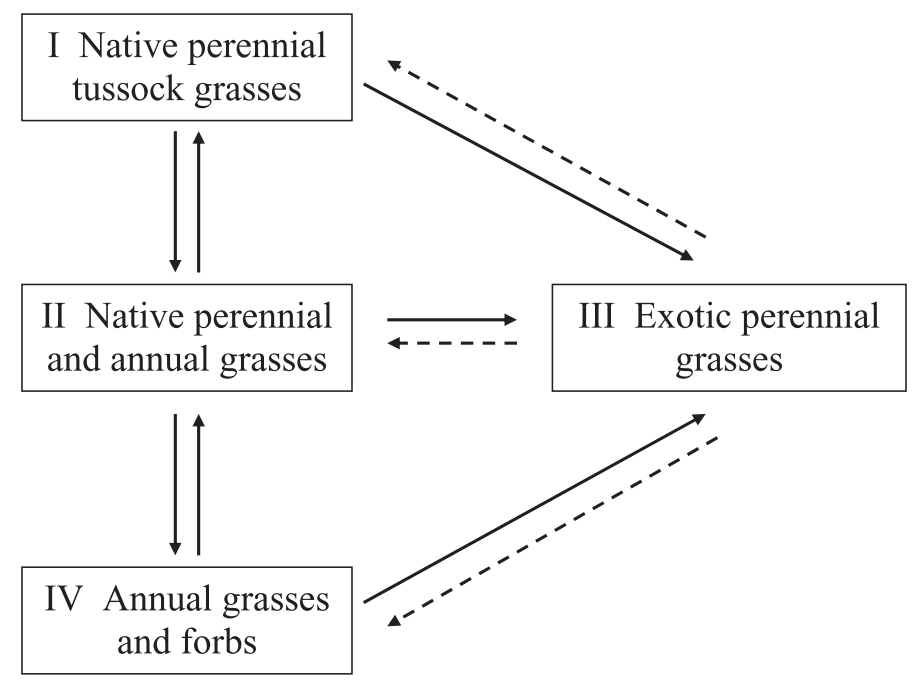

Figure 1. A state and transition model for tropical grasslands (adapted from Mclvor and Scanlan 1994). Solid lines indicate transitions that can be achieved through management, and dashed lines indicate transitions that are unlikely or will be difficult to achieve. 
Table 2. Herbaceous biomass and botanical composition of study sites at the start of the experiment before treatments commenced.

\begin{tabular}{|c|c|c|c|c|c|c|c|}
\hline \multirow[b]{2}{*}{ Site } & \multirow[b]{2}{*}{ State } & \multirow[b]{2}{*}{ Biomass } & \multicolumn{5}{|c|}{ Botanical composition } \\
\hline & & & $\begin{array}{l}\text { Decreaser perennial } \\
\text { grasses }\end{array}$ & $\begin{array}{c}\text { Increaser perennial } \\
\text { grasses }\end{array}$ & $\begin{array}{l}\text { Exotic perennial } \\
\text { grasses }\end{array}$ & Annual grasses & Other species \\
\hline & & $\mathrm{kg} \cdot \mathrm{ha}^{-1}$ & --------------------------- & --------------. & -------- \% ---------- & 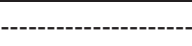 & -----------------. \\
\hline \multirow[t]{2}{*}{ Site A } & I & 2920 & 93.3 & 6.4 & 0.0 & 0.1 & 0.2 \\
\hline & II & 340 & 61.8 & 3.0 & 10.6 & 24.1 & 0.5 \\
\hline \multirow[t]{2}{*}{ Site B } & 1 & 3280 & 71.8 & 25.4 & 0.6 & 0.1 & 2.0 \\
\hline & II & 450 & 35.3 & 47.6 & 5.6 & 1.1 & 10.3 \\
\hline \multirow[t]{2}{*}{ Site C } & I & 1790 & 24.5 & 69.5 & 0.1 & 1.7 & 3.2 \\
\hline & II & 1050 & 12.7 & 77.2 & 0.0 & 1.6 & 8.6 \\
\hline
\end{tabular}

sericeum subsp. sericeum [R. Br.] A. Camus). State II still had decreaser perennial grasses present, but there were more increaser perennial grasses such as wire grasses (Aristida spp.), annual grasses such as liverseed grass (Urochloa panicoides P. Beauv.), Australian dropseed (Sporobolus australasicus Domin) and button grass (Dactyloctenium radulans [R. Br.] P. Beauv.), and forbs such as spiny sida (Sida spinosa L.), pigweeds (Portulaca spp.), tropical speedwell (Evolvulus alsinoides), and tarvines (Boerhavia spp.).

State I and II land conditions were chosen by selecting commercial paddocks near each other that had different grazing histories but were otherwise similar in land type. State I land had received lower grazing pressure in the preceding decade than State II land. For each land type State I was separated from State II by up to $10 \mathrm{~km}$. This was not ideal because of potential differences in rainfall between States I and II but was necessary to achieve differing land condition states on the same soil-vegetation type. The species composition and total herbaceous biomass for each land type and condition class at the start of the study are shown in Table 2. The difference between States I and II at Site C was less distinct than for the other two land types and reflects the lack of more suitable sites in this district. However, given the importance of similar lowfertility land types in northeast Queensland it was considered important to include this site in the study.

At each site and in each land condition state a number of grazing treatments were established by subdividing the total experimental area into a number of paddocks. There were two replicates of each grazing treatment in a randomized block design. A randomized block design was chosen over a completely randomized design to minimize the effects of spatial variability within the experimental areas.

A key aim of this study was to examine grazing management strategies to induce transitions between States I and II. The treatments differed between states as we believed that the grazing treatments likely to bring about a transition from State II to State I would be different from those that would drive a transition from State I to State II. For example, light grazing pressure and wet-season resting might be needed to facilitate a transition from State II to State I, but it is unlikely that the same combination would bring about a transition from State I to State II. It would have been preferable to have all the grazing treatments balanced, but land and resources did not allow all treatments to be imposed on both States I and II. The full suite of treatments is shown in Table 3.
Grazing treatments consisted of different pasture utilization rates (designated by $U$ and the level of utilization) with or without early wet-season resting (designated by $\mathrm{R}$ with + for rest and - for no rest). For the purposes of this study utilization is defined as the percentage of forage grown in a year that is consumed; for example, for $25 \%$ utilization (U25), one-quarter of the forage grown in that year is consumed. The utilization treatments aimed to achieve a wide range of grazing pressures from conservative $(25 \%$ utilization, U25) to moderate $(50 \%$ utilization, U50) to high (75\% utilization, U75). There was enough land available in the State II sites to establish ungrazed plots $(0 \%$ utilization, U0). Given this land had been adversely affected by previous grazing it was considered useful to include this treatment in the study of potential transitions to other states.

Paddock sizes were varied to achieve these different utilization rates; for example, U75 paddocks were one-third the size of U25 paddocks. For the utilization treatments without rest the intention was to achieve the utilization rate targets through year-round grazing that was as evenly distributed as possible through the year. This was important because it is known that there are differential responses to defoliation in different seasons of the year in these tropical systems (Ash and McIvor 1998). Because the amount of forage grown varied from year to year, the number of stock in each treatment was adjusted on approximately a monthly basis during the growing season, if required, to maintain target utilization rates in above- and below-average seasons. During

Table 3. Grazing treatments used at each site in the experiment.

\begin{tabular}{lcc}
\hline State & Utilization & Wet-season resting \\
\hline \multirow{1}{*}{ I } & $(\%)$ & \\
& 25 & No \\
& 50 & No \\
& 50 & Yes \\
& 75 & No \\
& 75 & Yes \\
& 0 & No \\
& 25 & No \\
& 25 & Yes \\
& 50 & No \\
& 50 & Yes \\
75 & No \\
\hline
\end{tabular}


the growing season these adjustments in stock numbers were based on rainfall received and visual assessments of herbage growth. At the end of the growing season the amount of herbage grown was assessed from measurements (see below). Individual paddocks varied in size from about 1 ha to 5 ha. This paddock scale was suitable for studying vegetation dynamics yet cost effective in establishment and maintenance of a wide range of treatments. The paddock size permitted grazing by only one or two animals, and paddocks were grazed for three or four days in each week. Previous experiments in this environment (McIvor and Gardener 1995) used a similar system of grazing in small paddocks, and the short rest periods (three or four days) between grazing were in themselves not considered sufficient to constitute a resting treatment in their own right in terms of plant dynamics and response to defoliation. We believe year-round grazing applied in this way approximates continuous grazing because there was some grazing every week and the periods when paddocks were not grazed were very short (threeto-four days). Even with animals in a paddock all the time the actual grazing on individual plants is not continuous. In a few years grazing was ceased altogether toward the end of the dry season when grasses were dormant (after ten or eleven months grazing) because it was deemed that utilization rates had been achieved. Brahman or Brahman-cross steers (200 to $350 \mathrm{~kg}$ liveweight) were used to graze the paddocks.

For wet-season resting treatments, rest from grazing commenced following the first significant rainfall event $(>50 \mathrm{~mm}$ over two days) from November onward. Paddocks were rested for eight weeks, and then the cattle were reintroduced.

Grazing treatments were established at Sites A and B in July 1992 and at Site C in October 1993. The experiment ran for eight years, concluding at the end of the growing season in May 2000 for Sites A and B and in May 2001 for Site C.

\section{Measurements}

All plots were sampled before the experimental treatments commenced and subsequently at the end of each growing season (April-May) and at the end of each dry season. The data were collected by measuring vegetation in 50 to 80 (the number used depended on paddock size) quadrats $(50 \times 50 \mathrm{~cm})$ along fixed transects in each paddock. Transects ran the length of each paddock (100-300 $\mathrm{m}$ depending on paddock size), and quadrats were spaced approximately evenly along each transect but specific locations were random. Vegetation data were collected and analyzed using the BOTANAL technique (Tothill et al. 1992), which involves visual estimation of pasture variables. In each quadrat the measurements were the following:

1) Species frequency-a record of all species present in each quadrat. Frequency is expressed as a percentage of the total number of quadrats (growing season only).

2) Botanical composition-relative proportions (of total biomass) of each species were visually assessed. While botanical composition was recorded at the species levels, for this paper the results have been combined into functional groups for presentation (decreaser native perennial grasses, increaser native perennial grasses, exotic perennial grasses, native annual grasses, and other species [legumes, forbs and sedges]).

3) Herbaceous biomass-the amount of herbage on offer.
4) Defoliation-the relative degree to which each species in a quadrat had been defoliated according to the following scale: 0 , no defoliation; $1,<5 \%$ of growth removed; 2 , $5-25 \% ; 3,25-50 \% ; 4,50-75 \%$; and 5, > 75\% (Andrew 1986) (dry season only).

5) Grass basal area-the percentage of ground occupied by the crowns of perennial grass plants (dry season only).

6) Ground cover-the percentage of ground covered by vegetative material (foliage plus litter) (growing season only).

In each of the U25 and U75 paddocks without rest, two $3 \times 3 \mathrm{~m}$ grazing exclosures were established to measure pasture growth over the growing season (October to May). Exclosures were established only in these two grazing treatments because they provided the likely greatest contrast in the effects of grazing on forage growth. In July or August these exclosures were erected and the senescent plant material from the previous growing season cut at $5 \mathrm{~cm}$ above ground level across the whole exclosure and removed. At the end of the next growing season (May), the herbaceous growth was cut to ground level in ten $0.5 \mathrm{~m} \times 0.5 \mathrm{~m}$ randomly placed quadrats within each exclosure and weighed to provide estimates of pasture growth. The exclosures were then moved to a new location for the next growing season to ensure that the cumulative effects of grazing on plant growth were being measured.

\section{Statistical Analyses}

Summary statistical analyses were conducted using Statistix for Windows (2004) and GenStat Release 8.1 (PC/Windows XP; 2005). As mentioned above, the grazing treatments were not balanced across land condition states, but this did not affect the analyses because they were conducted separately for each site and state. Although less powerful, this statistical approach of separately analyzing each site-state combination avoided pseudoreplication associated with the necessary selection of land condition states within which replication was then randomly applied within blocks. The responses to grazing treatments and interactions of grazing treatments with time for measured variables (herbaceous biomass, decreaser perennial grass biomass, ground cover, perennial grass basal cover, and defoliation estimates) were analyzed using the repeated measures option in GenStat.

\section{RESULTS}

\section{Rainfall and Growing Conditions}

Severe drought was experienced for the first four years of the study (1992-1996) followed by a series of above-average rainfall years (Table 4). Despite a number of drought years the rainfall threshold (50 $\mathrm{mm}$ over two days) required to trigger wet-season resting was achieved every year though the start date of resting varied from mid-November to mid-February across the eight years of the study.

\section{Vegetation Characteristics}

Table 5 shows the treatment effects using data from all years in a repeated measures analysis. At the three sites and in each of 
Table 4. Annual rainfall $(\mathrm{mm})$ from July-June for study sites on the three land types between 1992 and 2001.

\begin{tabular}{lccc}
\hline & Site A & Site B & Site C \\
\hline $1992-1993$ & 272 & 385 & 248 \\
$1994-1995$ & 253 & 356 & 304 \\
$1995-1996$ & 335 & 489 & 300 \\
$1996-1997$ & 465 & 440 & 489 \\
$1997-1998$ & 867 & 548 & 654 \\
$1998-1999$ & 778 & 849 & 465 \\
$1999-2000$ & 938 & 808 & 948 \\
$2000-2001$ & 773 & 620 & 699 \\
Long-term average & 546 & 676 & 662 \\
\hline
\end{tabular}

the two land condition classes grazing treatments had a significant effect on total herbaceous biomass, biomass of decreaser perennial grasses, ground cover, defoliation, and, with the exception of Site B State I, basal area of perennial grasses. Percentage frequency of decreaser perennial grasses was affected only by grazing treatments in State I at Site B. There was a strong year effect for nearly all variables, and this reflects the large interannual variability in rainfall experienced during the study, and in particular the sequence of dry years that was followed by a series of wet years. Significant grazing $\times$ time interactions were common, and these were related to cumulative effects of grazing through time.

To reduce the volume of data presented, only some of the results are included here. For example, it was expected that for the $25 \%$ utilization treatment on State II land, rest may have given some additional benefits over $25 \%$ utilization without rest. However, there was little difference between the U25 treatments (no rest, rest) in State II (Fig. 2), apart from some increases in biomass and frequency of decreaser grasses with rest at Site $\mathrm{C}$ in the later years. Therefore, for the most part, results through time are presented for key treatments relevant to management. However, some results are presented for all treatments to ensure adequate exposure of data across the range of utilization and resting treatments.

Defoliation. Estimates of plant defoliation indicate that the experiment achieved its objective of creating a range of utilization rates (Table 6). The estimates of defoliation suggest that at Site B the grazing treatments were close to the target utilization rates, while at Sites A and C defoliation levels were somewhat less than the target utilization rates, especially the $75 \%$ utilization rate. This may have had some impact on the plant responses and could explain some of the differences between sites reported below.

Biomass. Grazing treatments had a strong influence on both total and decreaser perennial grass biomass, with heavily grazed treatments (U75) having a significantly lower biomass than either lightly (U25) or moderately grazed treatments (U50) (Table 7; Fig. 3). The effect of $75 \%$ utilization on reducing biomass of decreaser perennial grasses increased as the trial progressed so that by the end of the study there were very large differences between heavily grazed and moderately grazed treatments. In nearly all treatments with rest, decreaser perennial grass biomass was higher than in treatments without rest (Table 7), though the magnitude of the benefit of rest was not large in $25 \%$ utilization treatments (State II only).

Pasture Growth. The exclosures revealed that the reduced biomass in U75 plots was not just due to biomass being consumed but was also due to a negative feedback effect of grazing on plant growth (Fig. 4). Apart from Site C State I, the heavily utilized plots had lower average yields over the experiment than the lightly utilized plots, and the decrease in

Table 5. Significance (probability) of treatment main effects (Grazing, Year) and treatment interactions for variables measured during the experiment.

\begin{tabular}{|c|c|c|c|c|c|c|c|c|}
\hline Land type & State & Effect & $\begin{array}{c}\text { Herbaceous } \\
\text { biomass }\end{array}$ & $\begin{array}{c}\text { Biomass of } \\
\text { decreaser } \\
\text { perennial grasses }\end{array}$ & $\begin{array}{c}\text { Frequency of } \\
\text { decreaser } \\
\text { perennial grasses }\end{array}$ & $\begin{array}{l}\text { Ground } \\
\text { cover }\end{array}$ & $\begin{array}{c}\text { Overall } \\
\text { defoliation }\end{array}$ & $\begin{array}{c}\text { Basal area of } \\
\text { perennial grasses }\end{array}$ \\
\hline \multirow[t]{6}{*}{ Site A } & I & Grazing & $<0.001$ & 0.002 & 0.192 & 0.035 & $<0.001$ & 0.007 \\
\hline & & Year & $<0.001$ & $<0.001$ & 0.003 & $<0.001$ & 0.070 & $<0.001$ \\
\hline & & Grazing $\times$ Year & 0.001 & 0.311 & 0.527 & 0.041 & 0.550 & 0.250 \\
\hline & II & Grazing & 0.008 & 0.060 & 0.206 & 0.023 & 0.023 & 0.098 \\
\hline & & Year & $<0.001$ & 0.001 & 0.001 & $<0.001$ & $<0.001$ & $<0.001$ \\
\hline & & Grazing $\times$ Year & 0.218 & 0.824 & 0.887 & 0.277 & 0.765 & 0.404 \\
\hline \multirow[t]{6}{*}{ Site B } & I & Grazing & 0.007 & 0.014 & 0.005 & 0.070 & 0.021 & 0.145 \\
\hline & & Year & $<0.001$ & $<0.001$ & 0.001 & 0.001 & $<0.001$ & 0.012 \\
\hline & & Grazing $\times$ Year & 0.241 & 0.007 & $<0.001$ & 0.021 & 0.248 & 0.513 \\
\hline & II & Grazing & 0.008 & 0.048 & 0.480 & 0.048 & $<0.001$ & 0.070 \\
\hline & & Year & $<0.001$ & $<0.001$ & $<0.001$ & $<0.001$ & $<0.001$ & $<0.001$ \\
\hline & & Grazing $\times$ Year & $<0.001$ & 0.024 & 0.512 & 0.856 & 0.670 & 0.181 \\
\hline \multirow[t]{6}{*}{ Site C } & I & Grazing & 0.054 & 0.173 & 0.732 & 0.062 & 0.024 & 0.005 \\
\hline & & Year & $<0.001$ & 0.001 & $<0.001$ & $<0.001$ & $<0.001$ & 0.001 \\
\hline & & Grazing $\times$ Year & 0.078 & 0.095 & 0.322 & 0.356 & 0.106 & 0.222 \\
\hline & II & Grazing & $<0.001$ & 0.003 & 0.208 & 0.039 & 0.012 & 0.001 \\
\hline & & Year & $<0.001$ & $<0.001$ & $<0.001$ & $<0.001$ & $<0.001$ & $<0.001$ \\
\hline & & Grazing $\times$ Year & 0.005 & 0.002 & 0.342 & 0.010 & 0.443 & 0.007 \\
\hline
\end{tabular}



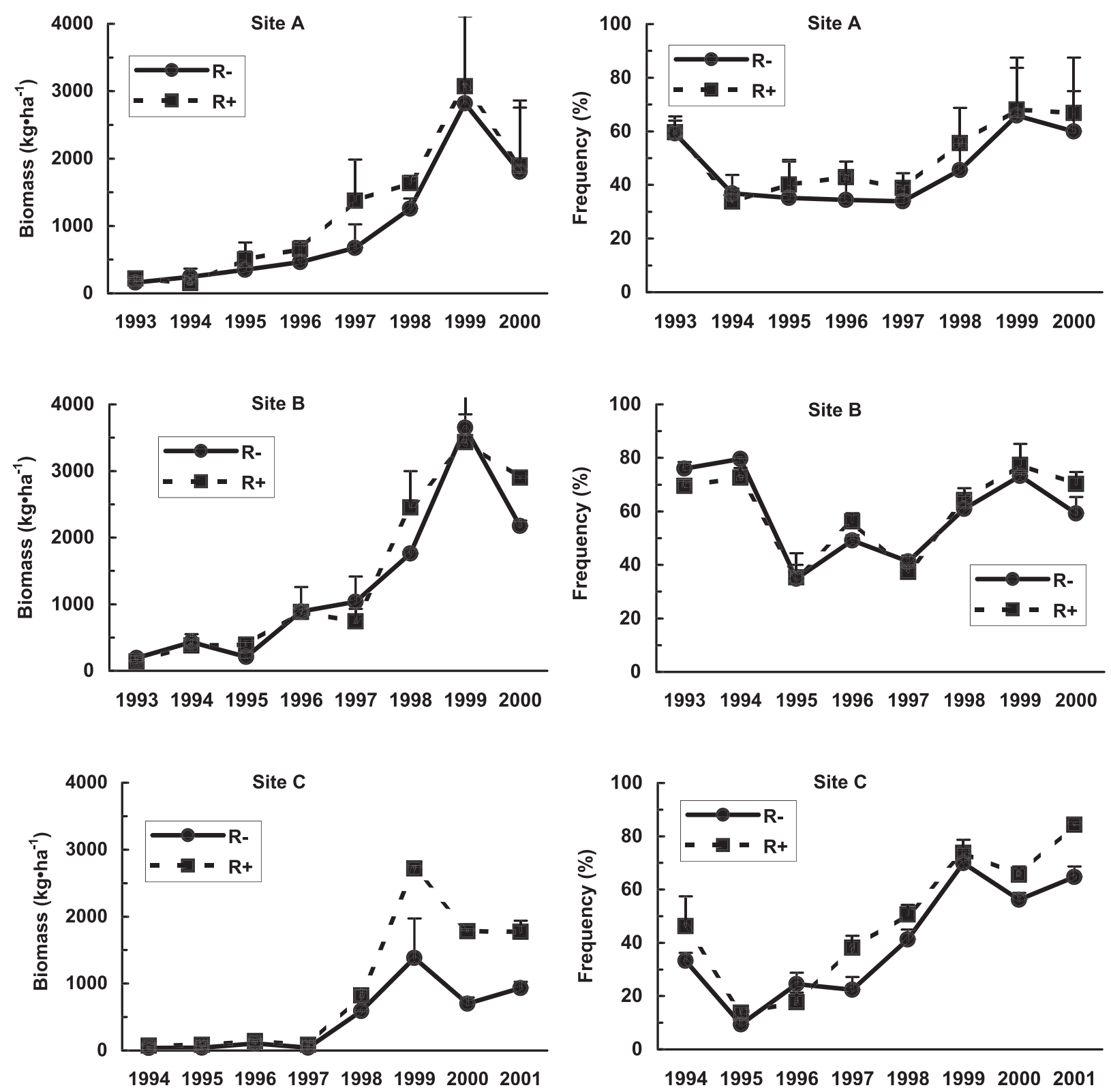

Figure 2. Effect of resting on changes in biomass and frequency of decreaser perennial grasses in plots with $25 \%$ utilization at three State II sites (mean and SE). The treatments are $25 \%$ utilization with no rest $(R-)$, and $25 \%$ utilization with rest $(R+)$.

yield with higher utilization was greater for State II than State I plots at all sites. This effect of grazing on plant growth was also detected through the numbers of grazing days required to achieve target utilization rates of $25 \%, 50 \%$, and $75 \%$. In the U75 treatments, the number of grazing days required to achieve the target utilization rate declined relative to the U25 treatments as the experiment progressed. For example, the number of grazing days at Site B to achieve $75 \%$ utilization was on average $70 \%$ that of the $25 \%$ utilization treatment after the first season of grazing. In contrast, the number of grazing days required to achieve $25 \%$ utilization in State II treatments increased through the trial because of recovery in pasture production.

Grass Basal Area and Ground Cover. Grazing had a significant effect on basal area of perennial grasses with increasing levels of utilization reducing basal area at all sites and in both land condition classes (Table 6). Although biomass of decreaser perennial grasses was similar for the U25 and U50R+ treatments, basal area of perennial grasses was lower in the $\mathrm{U} 50 \mathrm{R}+$ treatments than in the U25 treatments. Ground cover levels on the U75 plots were generally, but not always, lower than those on the U25 and U50 plots (Table 6).

Botanical Composition. There were significant differences in botanical composition between the three sites and between land condition classes within each site at the start of the experiment. Grazing treatments substantially changed species composition through the study, and this is highlighted in Figure 5, which shows the botanical composition in the first and last years of the experiment. At Sites A and B, decreaser perennial grasses dominated State I treatments at the start of the experiment. 
Table 6. Effect of grazing treatment on defoliation, basal area of perennial grasses, and ground cover. The values are the means over the experimental period.

\begin{tabular}{|c|c|c|c|c|c|c|c|c|c|}
\hline \multirow[b]{2}{*}{ Treatment } & \multicolumn{3}{|c|}{ Defoliation } & \multicolumn{3}{|c|}{ Basal area } & \multicolumn{3}{|c|}{ Cover } \\
\hline & Site A & Site B & Site C & Site A & Site B & Site C & Site A & Site B & Site C \\
\hline \multicolumn{10}{|l|}{ State I } \\
\hline U25R- & 21.7 & 26.2 & 29.1 & 1.17 & 1.65 & 1.02 & 74.5 & 68.4 & 60.0 \\
\hline U50R- & 30.4 & 41.7 & 39.1 & 1.15 & 1.31 & 0.64 & 77.1 & 69.9 & 52.7 \\
\hline U50R+ & 31.7 & 42.5 & 42.5 & 1.12 & 1.15 & 0.72 & 68.3 & 53.1 & 58.2 \\
\hline U75R- & 65.2 & 71.5 & 57.4 & 0.74 & 0.52 & 0.44 & 60.7 & 57.1 & 56.4 \\
\hline \multicolumn{10}{|l|}{ State II } \\
\hline U25R- & 33.3 & 26.7 & 20.7 & 1.03 & 1.31 & 0.84 & 63.9 & 62.3 & 59.3 \\
\hline U50R- & 50.1 & 44.4 & 36.8 & 0.87 & 0.87 & 0.54 & 62.3 & 56.4 & 56.3 \\
\hline U50R+ & 52.9 & 48.7 & 32.4 & 0.93 & 1.10 & 0.68 & 63.2 & 56.5 & 58.1 \\
\hline U75R- & 56.7 & 69.7 & 55.2 & 0.62 & 0.54 & 0.41 & 53.3 & 50.2 & 50.5 \\
\hline
\end{tabular}

However, decreaser perennial grasses declined in all grazing treatments, including the conservative U25 treatment. The decline in perennial grasses was greater at higher levels of utilization, especially at Site B, where by the end of the trial there were no decreaser perennial grasses remaining in the U75 treatment. This difference between sites in their response to high utilization rates may reflect differences in the actual rate of utilization achieved, which was noted above. Decreaser perennial grasses were largely replaced by exotic perennial grasses and also by native legumes at Site B; the proportions of these two functional groups increased with increasing level of utilization. The compositions of the U25 and U50R+ treatments were very similar at all sites despite quite different overall levels of utilization.

At Sites A and B, increaser perennial grasses and annual grasses were more prevalent in State II than State I at the start of the study. For both U25 and U50R+ treatments, the increaser perennial and annual grasses declined over the study and were

Table 7. Effect of utilization treatment and rest on decreaser perennial grass biomass $\left(\mathrm{kg} \cdot \mathrm{ha}^{-1}\right)$ for all treatments in the experiment. The values are for the last year of the experiment. Standard errors are shown in parentheses.

\begin{tabular}{lccc}
\hline Treatment & Site A & Site B & Site C \\
\hline State I & & & \\
U25R - & $2257(582)$ & $1231(24)$ & $2685(466)$ \\
U50R- & $1891(176)$ & $744(72)$ & $1113(567)$ \\
U50R+ & $2446(29)$ & $1127(146)$ & $1607(653)$ \\
U75R- & $658(29)$ & $2(2)$ & $483(102)$ \\
U75R+ & $1093(213)$ & $274(194)$ & $365(130)$ \\
State II & & & \\
U0 & $2184(406)$ & $4920(549)$ & No data \\
U25R- & $1743(617)$ & $2686(567)$ & $1306(271)$ \\
U25R+ & $1590(495)$ & $2980(175)$ & $1459(204)$ \\
U50R- & $287(91)$ & $1220(784)$ & $277(5)$ \\
U50R+ & $1396(582)$ & $2520(181)$ & $1249(316)$ \\
U75R- & $138(56)$ & $326(148)$ & $146(45)$ \\
\hline
\end{tabular}

replaced by decreaser perennial and exotic perennial grasses. With $75 \%$ utilization, decreaser perennial grasses declined further in State II and were replaced largely by exotic perennial grasses.

Exotic grasses played a major role in the change in species composition at Sites $\mathrm{A}$ and $\mathrm{B}$. The rapid invasion of treatment paddocks is highlighted in Figure 6. The main exotic grass invaders were Indian couch grass (Bothriochloa pertusa [L.] A. Camus) and Sabi grass (Urochloa mosambicensis [Hack.] Dandy) at Site B, and buffel grass (Cenchrus ciliaris L.) and Sabi grass at Site A. While all of these exotic grasses were quite common in the vicinity of the study sites at the commencement of the experiment, there were very few plants in the treatment paddocks with the exception of the Site A State II plots, which had significant presence of Sabi grass at the start of the study. There was a rapid increase in exotic grass abundance after the early dry years, and, for the most part, this was independent of utilization rate.

Site $\mathrm{C}$ was quite different from the other two sites in both starting composition and because exotic perennial grasses were not present at this site. Decreaser perennial grasses increased in all grazing treatments at Site $\mathrm{C}$ during the experiment, with the increase being greatest in the U25 and U50R+ treatments and least in the U75 treatment. In both States I and II, increaser perennial grasses declined and annual grasses and forbs increased during the trial in response to $75 \%$ utilization, with the increase in annual grasses and forbs being greatest in State II.

Species Frequency. Frequency percentage of individual plant species or functional groups can be a more sensitive indicator of plant dynamics than composition or biomass. Figure 7 shows how the frequency of decreaser perennial grasses responded to the different grazing treatments during the experiment. At Site B, $75 \%$ utilization clearly reduced the frequency of decreaser perennial grasses in both states, with the effect of high utilization most apparent in the latter half of the study. At Site A, 75\% utilization appeared to be decreasing the frequency of decreaser perennial grasses in State I during the first few years of the study when it was dry, but in the latter half of the experiment the presence of decreaser perennial grasses 

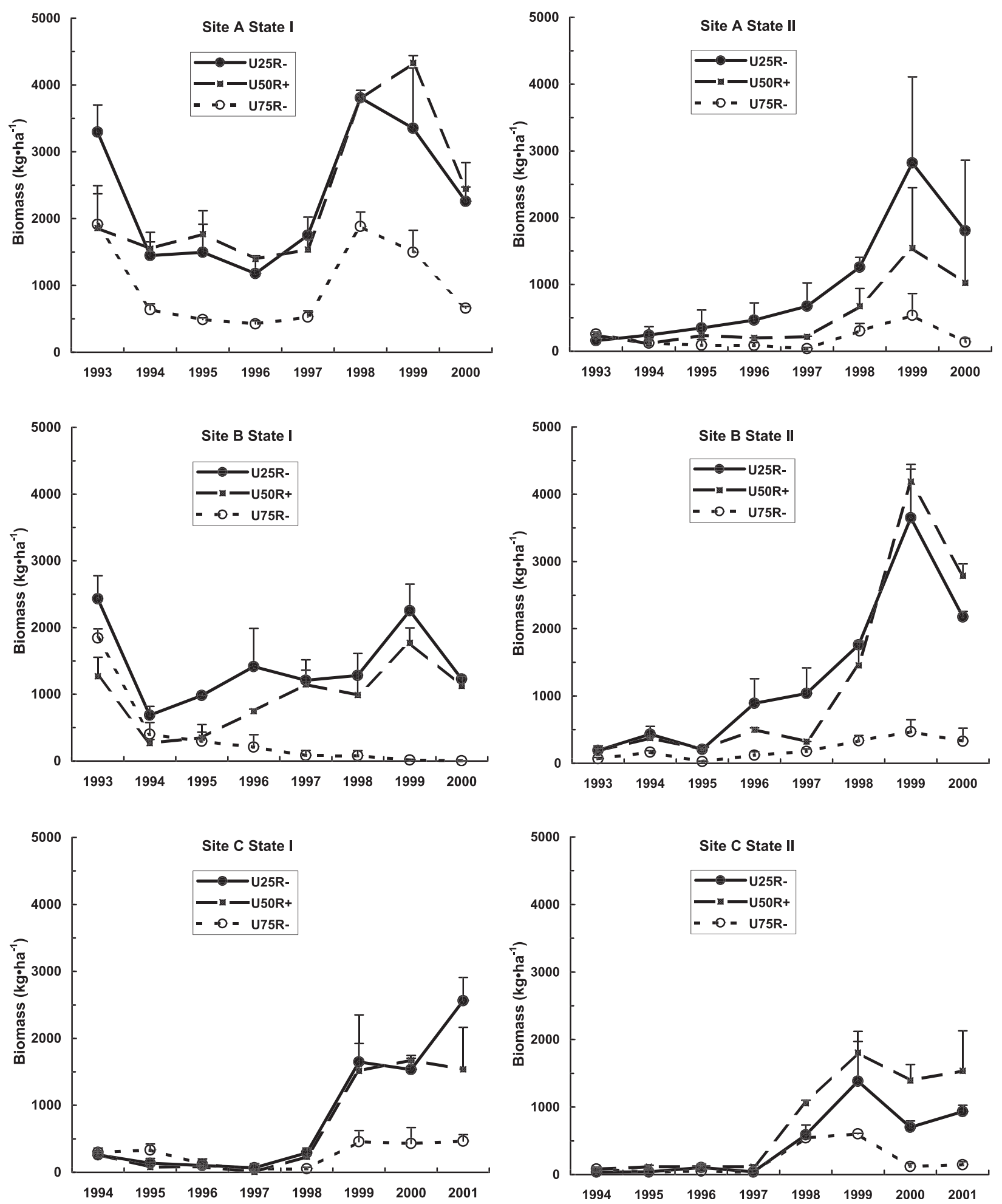

Figure 3. Effect of utilization rate and wet-season resting on biomass of decreaser perennial grasses (mean and SE). The treatments are $25 \%$ utilization with no rest (U25R-), 50\% utilization with rest (U50R+), and 75\% utilization with no rest (U75R-).

increased again. In State II there was a trend for $75 \%$ utilization to reduce the presence of decreaser perennial grasses. At Site C there was relatively little difference between utilization treatments in frequency of decreaser perennial grasses, although there was a tendency for the presence of these grasses to be reduced at $75 \%$ utilization at the end of the study (Table 8). A notable feature of Site $\mathrm{C}$ was the general trend of increasing frequency of decreaser perennial grasses as the experiment progressed.

By the end of the experiment, decreaser perennial grass frequency was higher in 10 of the 12 treatment comparisons involving rest, though the effect was significant only in six of these comparisons (Table 8). Decreaser perennial grass frequencies tended to respond more to rest in State II than in State I. 

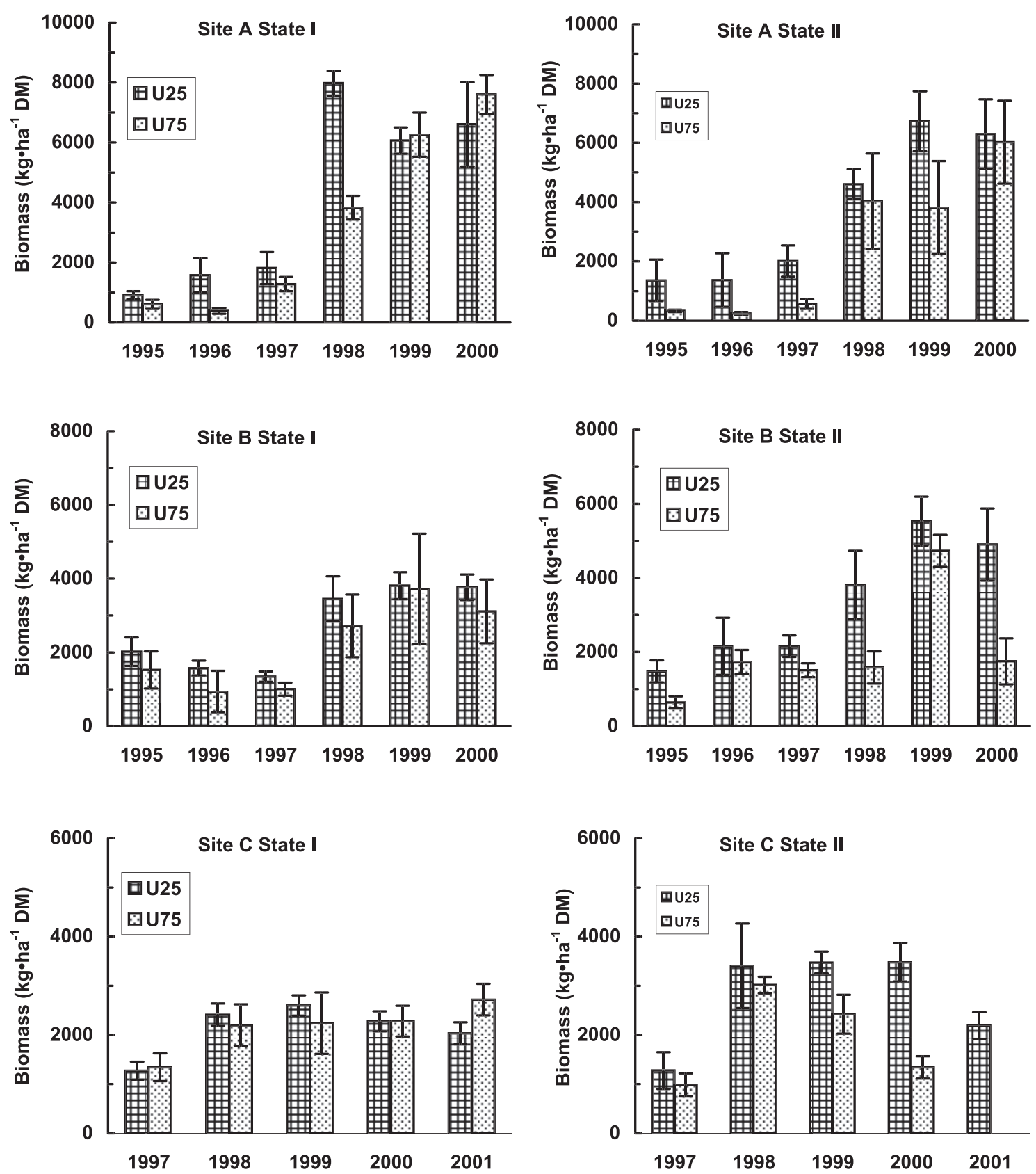

Figure 4. Cumulative effect of grazing on herbage production in a high utilization treatment (U75) compared with a light utilization treatment (U25) (mean and SE). The data were derived from exclosure cages shifted annually. There were no data for the U75 treatment at Site C State II in 2001.

\section{DISCUSSION}

The key objectives of this study were to determine how plant composition in structurally intact savanna woodlands responds to different grazing strategies, to determine if these changes could be placed in an ecological framework, and to examine how this understanding could be translated into management guidelines either to maintain land in good condition or to restore land with deteriorated native perennial grasses. The trial had a range of climatic extremes with an initial period of sustained drought followed by a series of above-average rainfall years. The sequence of dry years was the worst in recorded history and coincided with persistent El Niño conditions. The extent of the drought was evident by the widespread death of eucalyptus trees throughout the region (Fensham and Holman 1999). These drought years were followed by two "average" years and then three above-average rainfall years (1998-2000), which were consistent with La Niña conditions in the Pacific Ocean. The sequence of dry and wet years that occurred during the study provided a good contrast for exploring the effect of grazing and rainfall variability on vegetation dynamics.

We commenced the study with a simple state and transition model describing vegetation states and our understanding of the disturbances that drive transitions from one vegetation state to another. The results from the study, conducted on three differing land types, suggest that the state and transition models used to communicate vegetation change in the savanna woodlands of northeastern Australia are an accurate represen- 
Site A State I
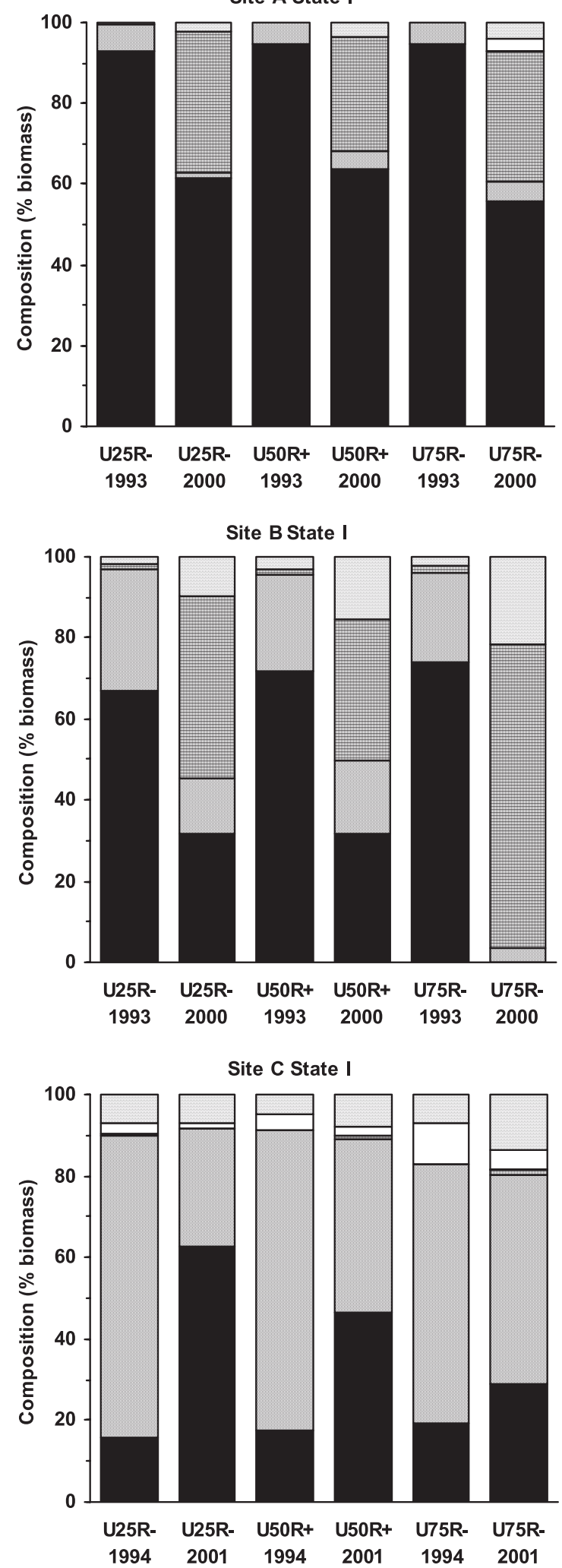
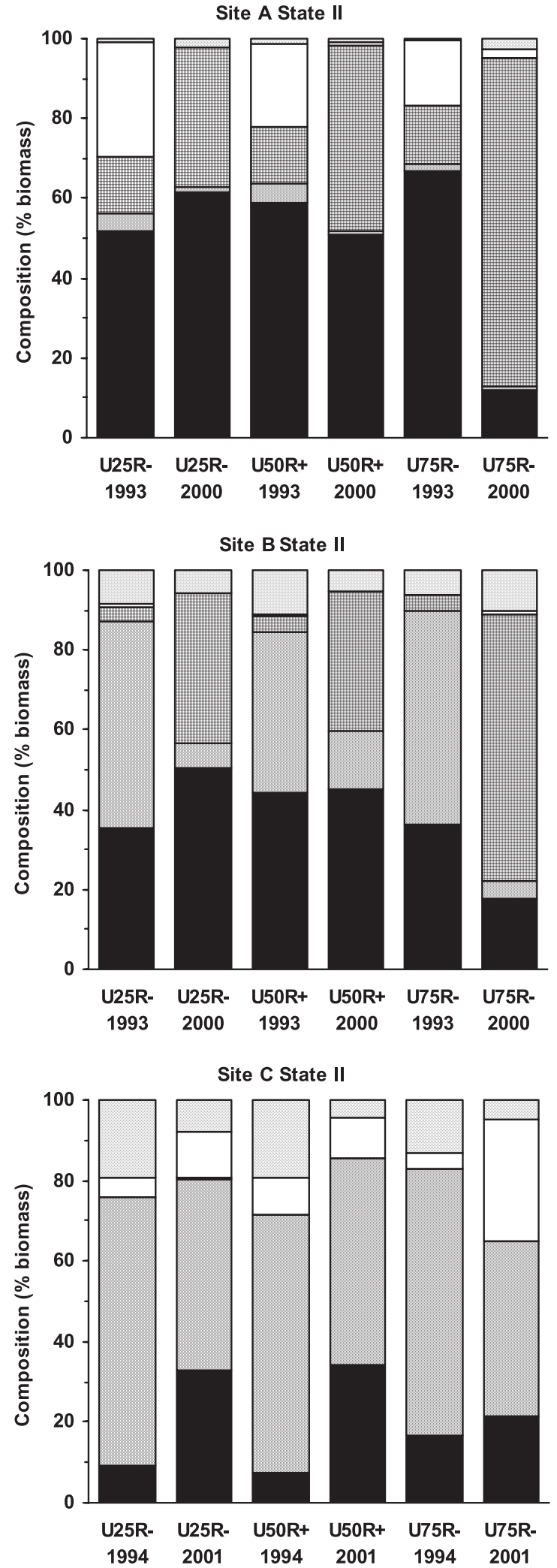

Figure 5. Botanical composition (proportion of herbaceous biomass) at the start (1992-1993) and at the end of the study (2000-2001) in response to grazing treatment. The treatments are $25 \%$ utilization with no rest (U25R-), $50 \%$ utilization with rest (U50R+), and $75 \%$ utilization with no rest $(\mathrm{U} 75 \mathrm{R}-)$. 

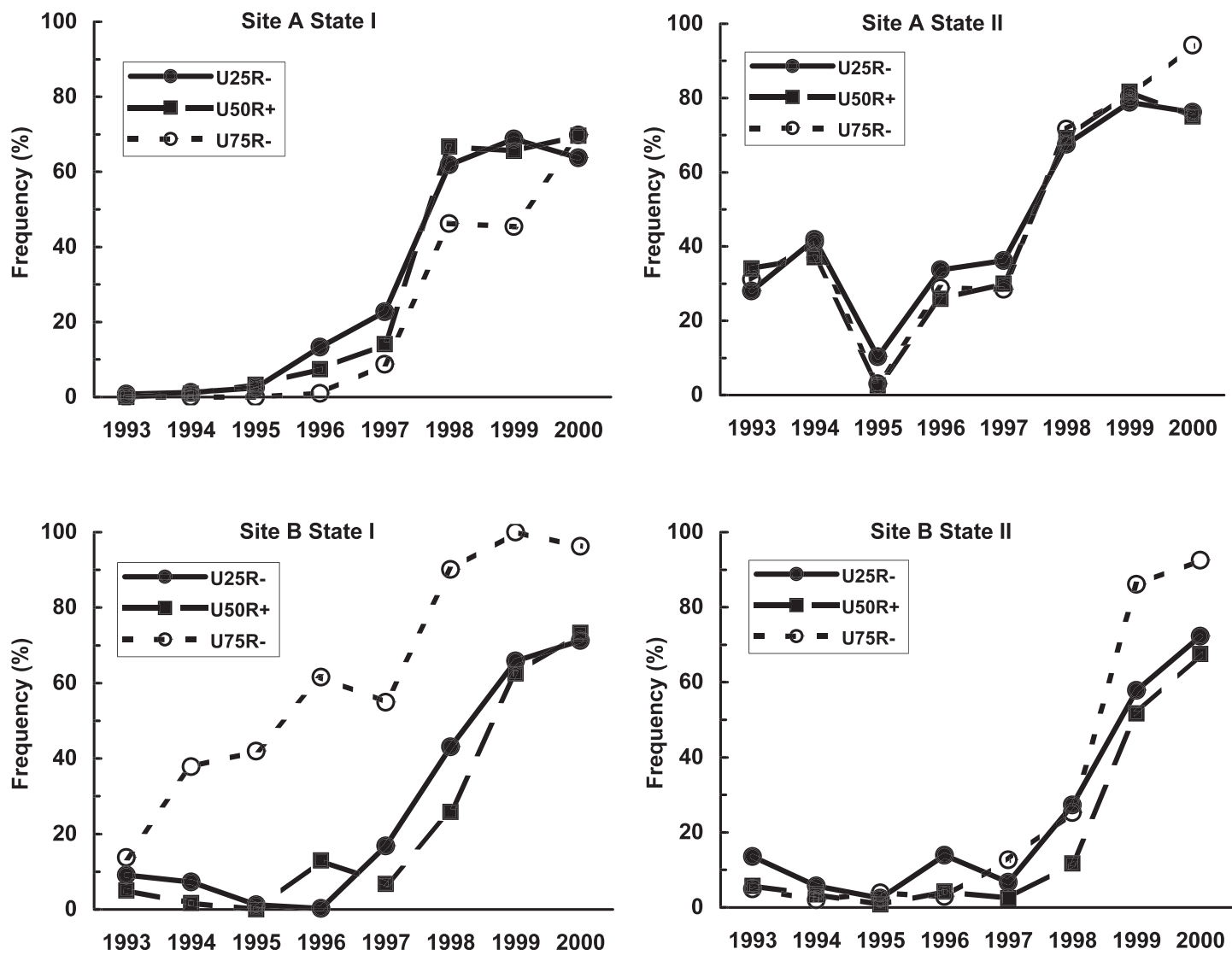

Figure 6. Changes in the frequencies of exotic perennial grasses under three grazing regimes at two experimental sites (mean and SE). The treatments are $25 \%$ utilization with no rest (U25R-), 50\% utilization with rest (U50R+), and 75\% utilization with no rest (U75R-).

tation of vegetation dynamics. In the absence of exotic perennial grasses (Site C) many of the vegetation changes were gradual with no obvious thresholds. However, at Sites A and B there was a rapid invasion by exotic grasses following the dry years, and this transition would appear to be irreversible, which is also consistent with the state and transition model proposed at the outset of this study. A more detailed discussion on the exotic plant invasion process follows later in the paper. This study also showed that vegetation that had been altered by previous high grazing pressures can recover toward its original vegetation state and that these transitions can be relatively gradual rather than threshold driven (Watson et al. 1996; Fuhlendorf et al. 2001), though climate sequences play an important role in the pattern and pace of recovery.

For land in State I condition at the start of the study, there were two grazing strategies that were consistently able to maintain a high frequency of decreaser perennial grasses. These were year-round grazing at $25 \%$ utilization or resting the pasture for the first eight weeks of the wet-season and then utilizing approximately $50 \%$ of the pasture biomass over the remainder of the year. Despite severe drought conditions for the first four years of the study, decreaser perennial grasses remained dominant in these grazing treatments and maintained their frequency and biomass throughout this period. However, the vigor of decreaser perennial grasses declined during the drought (as evidenced by a rapid decline in basal area of perennial grasses), recovering only with the wetter period experienced toward the end of the study. Based on a previous study in the region (McIvor and Gardener 1995), we expected year-round grazing at $25 \%$ utilization to be an effective grazing strategy to maintain decreaser perennial grasses. However, early wet-season resting followed by $50 \%$ utilization proved to be just as effective at maintaining the frequency and proportion of decreaser perennial grasses. The underlying basis for these benefits of wet-season resting is that with no grazing there is no removal of leaf area and consequent reduction in photosynthesis (Briske and Heitschmidt 1991). Native perennial grasses in northern Australia are particularly susceptible to grazing during the early growing season because a flush of tillering at this time means there are few new tillers to replace those killed by repeated defoliation (Mott et al. 1992). This, combined with a strong preference by cattle for decreaser perennial grasses during the growing season (Ash and McIvor 1998), results in these desirable species being able to tolerate only low to moderate levels of utilization. Providing rest during this early critical stage of the growing season may provide a buildup of energy reserves and sufficient leaf area for plants to tolerate much higher levels of utilization for the remainder of the year, and the results of this study support this hypothesis. A number of other studies in a range of environments have similarly demonstrated the benefits of strategic rest for vegetation composition (Dowling et al. 1996; Buttolph and Coppock 2004).

This study was based on annual utilization of pasture, that is, adjusting animal numbers from year to year to achieve target utilization rates. This approach to grazing management 

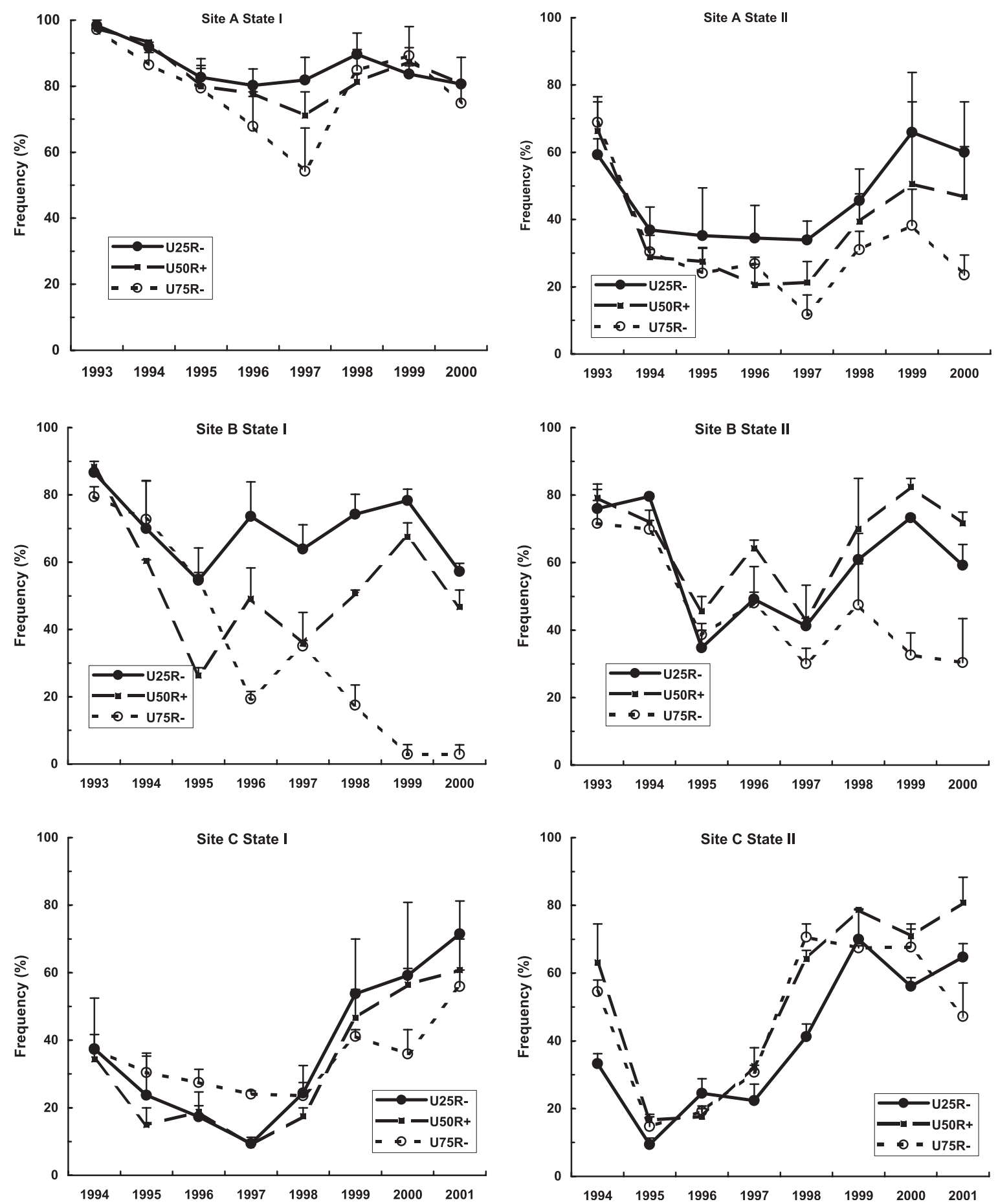

Figure 7. Changes in the frequencies of decreaser perennial grasses under three grazing regimes at three experimental sites (mean and SE). The treatments are $25 \%$ utilization with no rest (U25R-), $50 \%$ utilization with rest (U50R+), and $75 \%$ utilization with no rest (U75R-).

requires astute decision making and the capacity to significantly alter animal numbers from year to year. An alternative strategy is to stock at the same level each year to achieve an average utilization of $25 \%$, or $50 \%$ with wet-season resting. With this approach, utilization will be much higher than the long-term target in dry years when pasture productivity is low and vice versa in wet years with high plant productivity. Using constant stocking to achieve a long-term average utilization of $25 \%$ would lead to high utilization rates $(>60 \%)$ in $20-30 \%$ of years (McKeon et al. 1990; McIvor and Gardener 1995).
High levels of utilization $(75 \%)$ had a strong negative effect on the proportion and frequency of decreaser perennial grasses. This high level of utilization combined with drought during the first four years of the study was leading to a rapid decline of decreaser perennial grasses, which is consistent with results in other semiarid environments (O’Connor 1994, 1995; Holechek et al. 2003; Teague et al. 2004). However, four high-rainfall years during the second half of the study led to changing patterns in composition and frequency of decreaser perennial grasses that were strongly site dependent. At Site A, which is 
Table 8. Effect of utilization treatment and rest on decreaser perennial grass frequency (\%) for all treatments in the experiment. The values are for the last year of the experiment. Standard errors are shown in parentheses.

\begin{tabular}{lccc}
\hline Treatment & Site A & Site B & Site C \\
\hline State I & & & \\
U25R - & $80.6(8.10)$ & $57.3(2.45)$ & $71.5(9.75)$ \\
U50R - & $86.9(1.85)$ & $37.0(1.35)$ & $60.0(13.30)$ \\
U50R+ & $80.8(0.45)$ & $46.7(5.00)$ & $60.8(9.20)$ \\
U75R- & $74.8(5.60)$ & $2.9(2.85)$ & $55.9(4.90)$ \\
U75R+ & $74.9(14.05)$ & $24.1(8.70)$ & $49.9(6.75)$ \\
State II & & & \\
U0 & & & No data \\
U25R- & $57.2(5.27)$ & $89.4(3.29)$ & $68.4(3.18)$ \\
U25R+ & $59.8(10.76)$ & $67.6(8.68)$ & $78.5(4.60)$ \\
U50R- & $36.2(8.80)$ & $62.5(20.80)$ & $58.5(1.80)$ \\
U50R+ & $53.8(9.80)$ & $67.6(3.87)$ & $73.5(7.18)$ \\
U75R- & $23.5(5.90)$ & $30.4(13.05)$ & $47.2(9.90)$ \\
\hline
\end{tabular}

characterized by high fertility and well-structured soils, there was some short-term recovery of decreaser perennial grasses, even under heavy grazing, in response to favorable seasons following the drought. In contrast, Site B has lower-fertility, erosion-prone soils, and it is likely that the damage to the vegetation and soils in response to heavy utilization during the first half of the study did not allow the decreaser perennial grasses to recover when good seasons returned from 1997 to 2001. Indeed, pasture condition continued to decline during these better rainfall years, indicating a threshold in landscape function (Tongway and Whitford 2002) had been crossed and vegetation change was irreversible, at least in the short to medium term.

An important objective of this study was to examine the grazing management strategies needed to achieve a transition from State II to State I condition land. The results clearly demonstrated that recovery of decreaser perennial grasses was possible and that this recovery could occur quite rapidly. This was achieved using the same grazing strategies that maintained land in State I condition, that is, $25 \%$ utilization or wet-season resting followed by a higher level of utilization $(50 \%)$. Significant recovery of perennial grasses occurred during the first half of the study when drought conditions prevailed. This fairly rapid rate of recovery appears possible in semiarid grasslands (Bastin et al. 2003; Rose et al. 2004). However, the results from our study need to be interpreted in the context of the small spatial scale of the treatment paddocks (1-5 ha) and the nature of the grazing imposed (one or two animals per paddock rather than herds). The grazing patterns would not necessarily be representative of spatial grazing patterns in commercial enterprises where paddocks are typically many hundreds of hectares in size.

Using some of the key treatments in this experiment, a separate study (Ash et al. 1999) sampled contiguous quadrats along transect lines to explore spatial patterns of degradation and recovery. That study demonstrated biomass of perennial grasses recovered quite rapidly in State II treatments with $25 \%$ utilization or $50 \%$ utilization with wet-season resting, but the recovery was very patchy with large bare areas persisting between productive vegetated patches. Other work in these landscapes has demonstrated the importance of spatial patterning of herbaceous cover at multiple scales (Northup et al. 2005), and once large bare patches are created, it seems likely that it could take many years for landscapes to fully recover (Tongway and Whitford 2002; Ludwig et al. 2005).

Recovery in more arid rangelands can take decades (Fuhlendorf et al. 2001; Guo 2004; Valone and Sauter 2005). Rates of recovery may be closely linked to soil condition (Castellano and Valone 2007). In our study, although soil condition had declined, it did not appear to have reached a degraded state, and this may have assisted in recovery of perennial grasses. More recent work in applying the grazing management principles from this study in a commercial setting where the initial condition was degraded showed that recovery times are slower and strategic rest periods need to be of longer duration than the eight-week rests used in our study (Corfield and Nelson 2008).

Despite the fact that the frequency and biomass of decreaser native perennial grasses could be sustained by either conservative utilization rates year round or with higher grazing pressures following an early wet-season resting, significant species composition change did occur in these treatments at Sites A and B. This change in species composition was due to invasion by exotic perennial grasses, which were present in nearby paddocks before the experiment commenced. One of the exotic grasses, Indian couch grass, had been present in the region for many decades, whereas the other two exotic grasses, buffel grass and Sabi grass, were specifically introduced in the latter half of the 20th century as a means of improving forage and animal production. While these introduced species can provide significant benefits for livestock production, they can also significantly alter the composition of previously relatively intact rangelands (Cook and Dias 2006) and have deleterious effects on biodiversity (Smyth et al. 2009). The use of exotic grasses in tropical rangelands where the shrub and tree layer is relatively intact remains a vexed and contentious issue. Most pastoralists see the production benefits of these introduced grasses though the costs of establishment, which is not always successful, limits their widespread use. Exotic perennial grasses can provide just as good ground cover, and so from a soil erosion perspective they are generally as effective as native perennial grasses. They tend to dominate the herbaceous layer, hence the reason for a designated state (Fig. 1) in a state and transition context, noting that the transition to an exotic grass state is largely irreversible. It is this irreversibility of state and potential impact on biodiversity that has led to debates about the advantages and disadvantages of their use in semiarid and arid Australia (Friedel et al. 2006).

Although these exotic grasses were abundant in nearby paddocks, they were present only in a few of the experimental treatment plots at the start of the study in 1992 and at very low levels of abundance. They only increased dramatically following the severe drought of 1992-1997. It seems possible that the native perennial grasses were weakened sufficiently by the drought to create gaps in the pastures. The exotic grasses were able to establish in these gaps during the subsequent wetter years before the native species had time to recover, and the established exotic plants were then able to subsequently 
outcompete any later establishing native plants. The increase in exotic grasses also occurred in the ungrazed treatments $(0 \%$ utilization), further supporting the influence of climate rather than grazing as the trigger for the invasion. Another possible contributor to the expansion of exotic grasses is the often observed buildup of inorganic nitrogen in the soils of semiarid rangelands during drought (White et al. 2004). Increased nitrogen availability is likely to favor the establishment of exotic species.

Changes in vegetation composition, in both direction and rate of change, can be influenced by grazing and climate. The relative contributions of these drivers of vegetation can be difficult to untangle, but this study clearly shows that both are important in vegetation dynamics. Consistent with the analysis and interpretation of a long-term grazing study in a temperate rangeland (Fuhlendorf et al. 2001), it would appear in these tropical rangelands that grazing pressure has a strong influence on the long-term direction of native species composition, with climate being a stronger determinant of plant vigor (as measured by perennial grass basal area) and rates of vegetation change. This hypothesis is supported by other work in the region (McIvor and Gardener 1995), where native species composition was more affected by grazing treatment than by climate. In contrast, and as mentioned above, the invasion of exotic grasses appears to have been driven more by climate than grazing.

In other longer-term grazing trials in semiarid grasslands, the interaction between grazing and climate was quite different. For example, in South Africa, whether it was sourveld grazed by sheep (O'Connor and Roux 1995) or lowveld grazed by cattle (Fynn and O'Connor 2000), species change was primarily driven by rainfall variation, with grazing having a secondary, albeit important, effect on species composition. Similarly, in a short grass steppe in the United States, a range of grazing intensities had relatively little effect on species composition (Milchunas et al. 1998). Fuhlendorf et al. (2001) concluded that these differing responses to grazing and climate do not necessarily mean that they are mutually exclusive, but rather that they interact at different temporal scales that vary between ecosystems. These interactions and the response to grazing and climate are consistent with the evolutionary history of grazing model of Milchunas et al. (1988). The semiarid and arid grasslands of southern Africa and northern America have had a long evolutionary history of grazing and are relatively insensitive to grazing compared with the effects of rainfall. In contrast, the semiarid to subhumid grasslands and savannas of northern Australia have had a relatively short evolutionary history of grazing, as indicated earlier, and consistent with the model of Milchunas et al. (1988) grazing has a moderate to large effect on community composition.

The vegetation changes in this experiment are consistent with the state and transition model proposed as the underpinning framework. What has emerged is that both equilibrium and nonequilibrium vegetation dynamics can operate within a rangeland system. This outcome is aligned with recent reviews of equilibrium and nonequilibrium vegetation dynamics in rangelands (Briske et al. 2003; Buttolph and Coppock 2004). Some of the vegetation changes were relatively gradual, such as loss of perennial grasses in response to high utilization and recovery of perennial grasses with light utilization or wetseason resting. These gradual vegetation changes were primar- ily in response to grazing treatment. In contrast, the invasion of exotic grasses was quite sudden and occurred in response to an episodic climatic event. It also seems likely that the transition to dominance by exotic grasses is irreversible, at least on management timescales of years to decades, and is a clear example of nonequilibrium dynamics.

\section{MANAGEMENT IMPLICATIONS}

This study has shown that either conservative stocking with year-round grazing or a grazing system that includes some wetseason resting will help maintain land in a desirable state (State I) for sustainable pastoral production or facilitate the transition from a less ecologically desirable state (State II) to State I. The treatments of year-round grazing with a $25 \%$ utilization rate and wet-season resting followed by a $50 \%$ utilization rate gave similar vegetation responses, but the overall utilization was higher with the latter treatment, which may provide some opportunities to increase longer-term carrying capacity. Although this study has demonstrated benefits of wet-season resting on pasture attributes, there is little information available to assess implications for animal production and profitability. It had been assumed that maintaining healthy native perennial grass systems would prevent the ingress of exotic grasses, but this study has shown that a severe drought can provide the conditions that allow exotic grass establishment, largely independent of grazing management. In conclusion, this study has shown that the state and transition framework is robust when applied to grazed ecosystems in tropical rangelands and that grazing strategies can be applied in a practical way to achieve desired transitions. Climate variability can interact with the grazing strategies to influence the speed and nature of the transitions, but grazing is the key driver of rangeland condition.

\section{ACKNOWLEDGMENTS}

We thank pastoralists in the region, namely, I. F. Axford, T. H. Mann, R. Porter, C. P. Ferguson, M. J. Bredden, R. Rebgetz, and M. E. Pemble, for generous provision of land and support throughout the project. Bob Mayer provided statistical advice, and D. Cowan and G. Ford provided additional scientific and technical contributions to the experiment.

\section{LITERATURE CITED}

Allan, R. J., J. Lindesay, and D. E. Parker. 1996. El Niño southern oscillation and climatic variability. Collingwood, Australia: CSIR0 Publishing. 406 p.

AndREw, M. H. 1986. Selection of plant species by cattle grazing native monsoon tallgrass pasture at Katherine, N.T. Tropical Grasslands 20:120-127.

Ash, A. J., J. A. Bellamy, and T. G. H. Stockwell. 1994. Application of state and transition models to rangelands in northern Australia. Tropical Grasslands 28:223-228.

Ash, A. J., J. P. Corfield, And J. R. Brown. 1999. Patterns and processes in loss and recovery of perennial grasses in grazed woodlands of semi-arid tropical Australia. In: D. Eldridge and D. Freudenberger [EDS.]. People and rangelands, building the future. Proceedings of the 6th International Rangeland Congress; 19-23 July 1999; Townsville, Queensland, Australia. Volume 1, p. 229-230.

Ash, A. J., AND J. G. Mclvor. 1998. How season of grazing and herbivore selectivity influence monsoon tall-grass communities of northern Australia. Journal of Vegetation Science 9:123-132. 
Ash, A. J., AND J. G. Mclvor. 2005. Constraints to pastoral systems in marginal environments. In: J. A. Milne [ED.]. Pastoral systems in marginal environments. Proceedings of a satellite workshop of the XXth International Grassland Congress; July 2005; Glasgow, Scotland. Wageningen, The Netherlands: Wageningen Academic Publishers. p. 17-28.

Ash, A. J., J. G. Mclvor, J. P. Corfield, and W. H. Winter. 1995. How land condition alters plant-animal relationships in Australia's tropical rangelands. Agriculture, Ecosystems and Environment 56:77-92.

Ash, A. J., D. M. Stafford Smith, and N. Abel. 2002. Land degradation and secondary production in semi-arid and arid grazing systems. In: J. F. Reynolds and D. M. Stafford Smith [EDS.]. Global desertification: do humans cause deserts?. Berlin, Germany: Dahlem University Press. p. 111-134.

Bastin, G. N., J. A. Ludwig, R. W. Eager, A. C. Liedloff, R. T. Andison, and M. D. Cobiac. 2003. Vegetation changes in semiarid tropical savanna, northern Australia: 1973-2002. Rangeland Journal 25:3-19.

Bestelmeyer, B. T., J. R. Brown, K. M. Havstad, R. Alexander, G. Chavez, and J. HerRick. 2003. Development and use of state-and-transition models for rangelands. Journal of Range Management 56:114-126.

Briske, D. D., J. D. Derner, J. R. Brown, S. D. Fuhlendorf, W. R. Teague, K. M. Havstad, R. L. Gilleen, A. J. Ash, and W. D. Willms. 2008. Rotational grazing on rangelands: reconciliation of perception and experimental evidence. Rangeland Ecology \& Management 61:3-17.

Briske, D. D., S. D. Fuhlendorf, and F. E. Smeins. 2003. Vegetation dynamics on rangelands: a critique of the current paradigms. Journal of Applied Ecology 40:601-614.

Briske, D. D., S. D. Fuhlendorf, and F. E. Smeins. 2005. State-and-transition models, thresholds, and rangeland health: a synthesis of ecological concepts and perspectives. Rangeland Ecology \& Management 58:1-10.

Briske, D. D., and R. K. Heitschmidt. 1991. An ecological perspective. In: R. K. Heitschmidt and J. W. Stuth [EDS.]. Grazing management: an ecological perspective. Portland, OR, USA: Timber Press. p. 11-26.

Brown, J. R. 1994. Ecology as a basis for rangeland management. Tropical Grasslands 28:206-213.

Buttolph, L. P., AND D. L. Coppock. 2004. Influence of deferred grazing on vegetation dynamics and livestock productivity in an Andean pastoral system. Journal of Applied Ecology 41:664-674.

Castellano, M. J., and T. J. Valone. 2007. Livestock, soil compaction and water infiltration rate: evaluating a potential desertification recovery mechanism. Journal of Arid Environments 71:97-108.

Cook, G. D., AND L. DiAs. 2006. It was no accident: deliberate plant introductions by Australian government agencies during the 20th century. Australian Journal of Botany 54:601-625.

Corfield, J. P., and B. Nelson. 2008. Scaling up from Ecograze: the Virginia Park experience. Proceedings of the 15th Biennial Conference of the Australian Rangeland Society; September 2008; Charters Towers, Australia. (Compact Disc.)

Dowling, P. M., D. R. Kemp, D. L. Michalk, T. A. Klein, and G. D. Millar. 1996. Perennial grass response to seasonal rests in naturalised pastures of central New South Wales. Rangeland Journal 18:309-326.

Fensham, R. J., And J. E. Holman. 1999. Temporal and spatial patterns in droughtrelated tree dieback in Australian savanna. Journal of Applied Ecology 36:1035-1050.

Friedel, M., H. Puckey, C. O'Malley, M. Waycott, A. Smyth, and G. Miller. 2006. Buffel grass: both friend and foe. An evaluation of the advantages and disadvantages of buffel grass use and recommendations for future research. Alice Springs, Australia: Desert Knowledge Cooperative Research Centre. Report 17. p. 23-28.

Funlendorf, S. D., D. D. Briske, and F. E. Smeins. 2001. Herbaceous vegetation change in variable rangeland environments: the relative contribution of grazing and climatic variability. Applied Vegetation Science 4:177-188.

Fynn, R. W. S., And T. G. O'Connor. 2000. Effect of stocking rate and rainfall on rangeland dynamics and cattle performance in a semi-arid savanna, South Africa. Journal of Applied Ecology 37:491-507.

Gardener, C. J., J. G. MclvoR, and J. Williams. 1990. Dry tropical rangelands: solving one problem and creating another. Proceedings of the Ecological Society of Australia 16:279-286.
Guo, Q. F. 2004. Slow recovery in desert perennial vegetation following prolonged human disturbance. Journal of Vegetation Science 15:757-762.

HodGKINSON, K. 1995. A model for perennial grass mortality under grazing. In: N. E. West [ED.]. Rangelands in a sustainable biosphere. Proceedings of the Fifth International Rangeland Congress. Denver, CO, USA: Society for Range Management. p. 240-241.

Holechek, J., D. E. E. Galt, J. Joseph, J. Navarro, G. Kumalo, F. Molinar, and M. Thomas. 2003. Moderate and light cattle grazing effects on Chihuahuan Desert rangelands. Journal of Range Management 56:133-139.

IsBELL, R. F. 1996. The Australian soil classification. Melbourne, Australia: CSIRO. $143 \mathrm{p}$.

Kerridge, P. C., M. A. Gilberert, and D. B. Coates. 1990. Phosphorus and beef production in northern Australia. 8. The status and management of soil phosphorus in relation to beef production. Tropical Grasslands 24:221-230.

Landsberg, R. G., A. J. Ash, R. K. Shepherd, and G. M. McKeon. 1998. Learning from history to survive in the future: management evolution on Trafalgar station, north-east Queensland. Rangeland Journal 20:104-118.

Ludwig, J. A., B. P. Wilcox, D. D. Breshears, D. J. Tongway, and A. C. Imeson. 2005. Vegetation patches and runoff-erosion as interacting ecohydrological processes in semiarid landscapes. Ecology 86:288-297.

Mclvor, J. G., A. J. Ash, ANd G. D. Cook. 1995. Land condition in the tropical tallgrass pasture lands: 1 . Effects on herbage production. Rangeland Journal 17:69-85.

Mclvor, J. G., AND C. J. Gardener. 1995. Pasture management in semi-arid tropical woodlands: effects on herbage yields and botanical composition. Australian Journal of Experimental Agriculture 35:705-715.

Mclvor, J. G., S. Mclntyre, I. Saeli, and J. J. Hodgkinson. 2005. Patch dynamics in grazed sub-tropical native pastures in south-east Queensland. Austral Ecology 30:445-464.

Mclvor, J. G., AND D. M. ORR. 1991. Sustaining productive pastures in the tropics. 3. Managing native grasslands. Tropical Grasslands 25:91-97.

Mclvor, J. G., AND J. C. Scanlan. 1994. State and transition models for rangelands. 8. A state and transition model for the northern speargrass zone. Tropical Grasslands 28:256-259.

McKeon, G. M., K. A. Day, S. M. Howden, J. J. Mott, D. M. Orr, W. J. Scattini, and E. J. Weston. 1990. Northern Australian savannas: management for pastoral production. Journal of Biogeography 17:355-372.

Milchunas, D. G., W. K. Lauenroth, And I. C. BuRke. 1998. Livestock grazing: animal and plant biodiversity of shortgrass steppe and the relationship to ecosystem function. Oikos 83:65-74.

Milchunas, D. G., O. E. Sala, and W. K. Lauenroth. 1988. A generalized model of the effects of grazing by large herbivores on grassland community. American Naturalist 132:87-106.

MotT, J. J. 1987. Patch grazing and degradation in native pastures of the tropical savannas in northern Australia. In: F. P. Horn, J. Hodgson, J. J. Mott, and R. W. Brougham [EDS.]. Grazing-lands research at the plant-animal interface. Morrilton: Winrock International. p. 153-161.

Mott, J. J., M. M. Ludlow, J. H. Richards, and A. D. Parsons. 1992. Effects of moisture supply in the dry season and subsequent defoliation on persistence of the savanna grasses Themeda triandra, Heteropogon contortus and Panicum maximum. Australian Journal of Agricultural Research 43:241-260.

Norman, M. J. T. 1965. Post-establishment grazing management of Townsville lucerne on uncleared land at Katherine, N.T. Journal of the Australian Institute of Agricultural Science 31:311-313.

Northup, B. K., C. D. Dias, J. R. Brown, and W. C. Skelly. 2005. Micro-patch and community scale spatial distribution of herbaceous cover in a grazed eucalypt woodland. Journal of Arid Environments 60:509-530.

O'ConnoR, T. G. 1994. Composition and population responses of an African savanna grassland to rainfall and grazing. Journal of Applied Ecology $31: 155-171$

O'ConnoR, T. G. 1995. Transformation of a savanna grassland by drought and grazing. African Journal of Range and Forage Science 12:53-60.

O'Connor, T. G., ANd P. W. Roux. 1995. Vegetation changes (1949-79) in a semiarid, grassy dwarf shrubland in the Karoo, South Africa: influence of rainfall variability and grazing by sheep. Journal of Applied Ecology 32:612-626. 
Phelps, D. G., and O. J. H. Bosch. 2002. A quantitative state and transition model for the Mitchell grasslands of central western Queensland. Rangeland Journal 24:242-267.

Pratt, D. J., and M. D. Gwynne. 1977. Rangeland management and ecology. Huntington, NY, USA: Robert E. Krieger Publishing. 310 p.

Rogers, L. G., M. G. Cannon, and E. V. Barry. 1999. Land resources of the Dalrymple Shire. Volume 1. Brisbane, Australia: Queensland Department of Natural Resources Land Resources, Bulletin DNRQ 980090. 120 p.

Rose, A. B., P. A. Suisted, and C. M. Frampton. 2004. Recovery, invasion, and decline over 37 years in a Marlborough short-tussock grassland, New Zealand. New Zealand Journal of Botany 42:77-87.

SCAnLAN, J. C. 1994. State and transition models for rangelands. 5. The use of state and transition models for predicting vegetation change in rangelands. Tropical Grasslands 28:229-240.

SMiтH, E. L. 1960. Effects of burning and clipping at various times during the wet season on tropical tall grass range in northern Australia. Journal of Range Management 13:197-203.

Smyth, A., M. Friedel, and C. O'Malley. 2009. The influence of buffel grass (Cenchrus ciliaris) on biodiversity in an arid Australian landscape. Rangeland Journal 31:307-320.

Soll Survey StafF. 1990. Keys to soil taxonomy. 4th ed. SMSS Technical Monograph No. 6. Blacksburg, VA, USA: Virginia Polytechnic Institute and State University.

Tainton, N. M. 1999. Veld management in South Africa. Pietermaritzburg, South Africa: University of Natal Press. $472 \mathrm{p}$.

Tainton, N. M., R. H. Groves, And R. Nash. 1977. Time of mowing and burning veld: short term effects on production and tiller development. Proceedings of the Grassland Society of Southern Africa 12:59-64.
Teague, W. R., S. L. Dowhower, and J. A. Waggoner. 2004. Drought and grazing patch dynamics under different grazing management. Journal of Arid Environments 58:97-117.

Tongway, D., AND W. Whitford. 2002. Desertification and soil processes in rangelands. In: A. C. Grice and K. C. Hodgkinson [EDs.]. Global rangelands: progress and prospects. Wallingford, UK: CABI Publishing. p. 55-62.

TothilL, J. C., AND C. Gillies. 1992. The pasture lands of northern Australia. Brisbane, Australia. Tropical Grassland Society of Australia Occasional Publication No. 5. 106 p.

Tothill, J. C., J. N. G. Hargreaves, R. M. Jones, and C. K. McDonald. 1992. BOTANAL: a comprehensive sampling and computing procedure for estimating pasture yield and composition. 1. Field sampling. Brisbane, Australia. CSIRO Division of Tropical Crops and Pastures Tropical Agronomy Technical Memorandum No. 78.

Valone, T. J., and P. Sauter. 2005. Effects of long-term cattle exclosure on vegetation and rodents at a desertified arid grassland site. Journal of Arid Environments 61:161-170.

Watson, I. W., D. G. Burnside, And A. M. Holm. 1996. Event-driven or continuous: which is the better model for managers? Rangeland Journal 18:351-369.

Westoby, M., B. H. Walker, and I. Noy-Meir. 1989. Opportunistic management for rangelands not at equilibrium. Journal of Range Management 42: 266-274.

White, C. S., D. I. Moore, and J. A. Craig. 2004. Regional-scale drought increases potential soil fertility in semiarid grasslands. Biology and Fertility of Soils 40:73-78.

Woinarski, J., B. Mackey, H. Nix, and B. Tralll. 2007. The nature of northern Australia: natural values, ecological processes and future prospects. Canberra, Australia: ANU E Press. 127 p. 